\begin{tabular}{l} 
RCCS \\
\hline Annual Review
\end{tabular}

\section{RCCS Annual Review}

A selection from the Portuguese journal Revista Crítica de Ciências Sociais

1 | 2009

Issue no. 1

\title{
What Makes Social Networks Move? An Analysis of Norms and Ties
}

\section{Sílvia Portugal}

Translator. Sheena Caldwell

\section{OpenEdition}

\section{Journals}

Electronic version

URL: http://journals.openedition.org/rccsar/150

DOI: $10.4000 /$ rccsar. 150

ISSN: $1647-3175$

\section{Publisher}

Centro de Estudos Sociais da Universidade de Coimbra

\section{Electronic reference}

Sílvia Portugal, « What Makes Social Networks Move? An Analysis of Norms and Ties », RCCS Annual Review [Online], 1 | 2009, Online since 01 September 2009, connection on 30 April 2019. URL : http:// journals.openedition.org/rccsar/150 ; DOI : 10.4000/rccsar.150 


\section{Sílvia Portugal}

School of Economics and Centre for Social Studies, University of Coimbra, Portugal

\section{What Makes Social Networks Move? An Analysis of Norms and Ties*}

This paper discusses the norms that regulate the action of informal ties in the production of wellbeing. It shows that the action of social networks follows the general principles of the gift system, that is to say, the triple obligation of "giving, receiving, and reciprocating" structures actors' practices and representations. However, the author also addresses the problems arising out of these guiding principles. Reciprocity, obligation, equality, autonomy - these rules are clear, but a detailed analysis reveals contradictory principles, as well as resistance, tension and conflict.

Keywords: Social networks; norms; gift system; reciprocity; obligation.

\section{Introduction}

This article is based on an empirical research study that analysed the role of social networks in providing resources (Portugal, 2006) in order to discuss the norms which regulate the action of informal ties in the production of well-being. The qualitative research was based on 60 in-depth interviews administered to men and women integrated into the formal labour market, married or cohabiting, with or without children, and aged between 25 and 34 . I therefore chose to focus the analysis on the initial phase of the family life cycle, seeking out a time in which material and affective resources are (re)organized, in order to test out the role of social networks.

The research traced the morphology of family networks, identifying interaction networks, exchange networks and close associates networks, and analysed the flows within them, identifying the role of the different types of ties in terms of various resources (employment, housing, health, material possessions). The work clearly showed the permanence and vitality of the gift system in the circulation of goods and services. On the one hand, empirical data showed that social networks were central to satisfying the needs of families, and that informal ties were essential to providing everyday support for family life. The interviews revealed how countless resources, forms of support, affections, goods and services circulated within these networks. On the other hand, the analysis of the morphology of the networks activated for each of these resources revealed how a partial network was activated for each domain (Boissevain, 1974), involving the ties that could best respond to the needs

\footnotetext{
${ }^{*}$ Article published in RCCS 79 (December 2007).
} 
of individuals and their families. Thus, whilst for certain resources the network was based on strong ties ${ }^{1}$ and kinship, for others weak ties were essential in guaranteeing the provision of needs.

This article aims to assess the norms which regulate these intense flows. Whilst the research shows that the circulation of exchanges within the networks obeys the general principles of the gift, as described by Marcel Mauss in Essai sur le Don (The Gift), originally published in $1924,{ }^{2}$ the discourse of the individuals interviewed also points to the ambiguous and contradictory nature of these principles, bringing their complexity to light.

\section{Norms and ties}

By definition, norms tell individuals how they should behave and what they should expect of others. Norms reduce uncertainty and help to define "how things should be" in a particular group. Problems arise when the behaviour of actors evades the established norms, or when their expectations are thwarted. Norms can be divided into three main types (Therborn, 2002): constitutive norms, which define a system of action and an actor's membership within it; regulative norms, which govern an actor's expected contribution to the system; and distributive norms, which define how rewards, costs and risks should be allocated. In other words, norms define membership of a group, expected contributions and the appropriate reward for each contribution. For Therborn, these three types of norms differ in importance and have different dynamics: constitutive or behavioural norms are of primary importance, as they are more internalised and define what constitutes appropriate and full membership of a particular social system. They are what enables individuals to "behave themselves". However, distributive norms tend to provoke stronger reactions if violated. A sense of injustice tends to be the driving force behind actions. Regulative norms are an important criterion for attributing status within the social system (Therborn, 2002: 870).

This article seeks to assess the role of these norms and the problems raised by their application within social networks. Why does one person help another? Why does one person receive help from others? What expectations do givers and receivers have? Which

\footnotetext{
${ }^{1}$ Granovetter's criteria were used to distinguish between strong and weak ties $(1973,1982)$ : duration of relationship (length of relationship and time spent together), emotional intensity, intimacy, reciprocal services. A fifth a criterion was added, suggested by Degenne and Forsé (1994): "multiplexity," i.e. the plurality of exchange contents within a tie.
} 
norms regulate exchanges within networks? What is considered right and wrong, fair or unfair? How are obligations defined? Do different ties obey different principles?

Research indicates an affirmative answer to the last of these questions, which therefore affects, to a large extent, the answers to the other questions. The norms which regulate interaction within networks depend on the type of tie that is at stake. What is right or wrong, fair or unfair, owing or not, depends on the nature of the relationship concerned. Norms reflect a relationship between people, rather than a balance between what is exchanged. As Kellerhals et al. argue (1995), the sense of justice is primarily sign of a relational project, a "recognition of people."

Jean Kellerhals and his collaborators have developed important work on the criteria which govern distributive justice (who is entitled to what?) and procedural justice (how do we arrive at a fair decision?) (Kellerhals et al., 1995; 1987 and 1988). In the book Figures de l'équité. La construction des normes de justice dans les groupes (Kellerhals et al.,1988), the authors identify five general questions which structure the definition of justice within groups. The first question is concerned with the distribution norm: what rule should be used to distribute scarce resources? Need, merit, equality or some other criterion? Secondly, putting this principle into action implies the intervention of assessment norms or criteria which enable the value of contributions and the situation of the members of the group taking part in an exchange to be defined. Thirdly, the comparison norm defines how status and social identity are important for internal decisions on justice: are these categories disregarded or, conversely, so important that the distribution and assessment norms operate in relation to them? Any of these options may be affected by the nature of the resource in question, meaning that, fourthly, the transformation rule is applied: can the same rules and criteria be used to distribute different kinds of resources?

Finally, the authors emphasise that these four aspects of the decisions on justice are influenced by the problem of the appropriation norm. This involves understanding how a group constitutes the mass of resources which it then proceeds to distribute. The appropriation norm defines whether individual entitlements to ownership that prevail outside the group are maintained within it, or whether, conversely, the group at any given

\footnotetext{
${ }^{2}$ For an interesting analysis of the work of Mauss and his contemporary relevance, see Martins (2005).
} 
moment defines the rights of ownership of its members. In the former case, the individual defines the boundaries of the group, whereas in the latter case the reverse occurs.

The research led to the conclusion that the application of these criteria to the network as a whole depends on the nature and strength of the ties and resources in question. In other words, the comparison norm (defining the network tie) and the transformation norm (defining the resource in question) take precedence over the distribution norm. On the one hand, the criteria which define justice in relation to contributions and rewards are applied differently inside and outside the kinship network. As Alexis Ferrand states, "the beauty and, at times, the horror of family ties lie in their capacity to decree the equivalent value of totally heterogeneous forms of help" (Ferrand, 1992: 89). On the other hand, the type of resource at stake leads to a re-evaluation of the way in which the norms are applied. Different kinds of resources require different criteria, both inside and outside the family. If parents have more than one child and give money to one of them, the prevailing norm is that of equality - everyone should receive the same. However, if grandparents have more than one grandchild and take care only of the one closest to them, the accepted criterion is that of a combination of need and proximity.

These conclusions are similar to those of Jacques Godbout in his reflections on the application of the norms of justice in family relationships (Godbout, 1995). The author analyses three separate exchange circuits - help with services, presents and hospitality - and concludes that the criteria governing each of these situations are different. Godbout reaches a conclusion which is similar to mine: the justice norm is difficult to apply within family networks. As we shall see later, it only serves as the dominant principle when applied to the comparison between different rewards for the same contribution. In other words, the principle does not apply between giver and receiver, but between different givers and different receivers. As Godbout states, in family networks the idea of justice does not relate directly to the relationship between contribution-reward, but to the comparison between "peers" (givers or receivers) in relation to a third party (1995: 361).

\section{Reciprocity, but ...}

The first question that is raised when considering the principles that regulate the networks of material or affective exchanges is whether there is a restricted or a generalized exchange. This question is related to fundamental ethnological and anthropological distinctions. 
However, in this case it is not a matter of applying the complete theory as elaborated by Lévi-Strauss, but of retaining "the intuition of the issue" (Degenne and Lebeaux, 1997: 124). If the exchange is based on gifts and counter-gifts, it is to be expected that a certain balance will be achieved. In restricted exchanges, one gift calls for another gift in return, even if it is of a different kind. A friend finds me a job, and I offer him dinner to celebrate; a neighbour manages to speed up the waiting time for a hospital appointment, and I give her a Christmas present. There is a direct reciprocity, a symmetrical exchange that is restricted to the pair in question. In a generalized exchange, the balance is established in terms of the group. Reciprocity is diffused and deferred over time. I help my brother to build his house and one day my mother will give me a plot of land so that I can build a house of my own.

Following Ekeh, Lemieux argues that these two types of exchange have different consequences for the solidarity of the groups in which they take place. Contrary to the arguments of other specialists, he states that restricted exchange is a source of tension and instability, given that it rests on a weak level of mutual trust, whilst generalized exchange is based on a strong level of trust within the group of actors involved. The person who receives does not repay the giver, but the latter is confident that someone in the network will repay them one day (Lemieux, 1999: 61-62). On the basis of their analysis of the results of a survey carried out in France at the end of the 1980s, Degenne and Lebeaux conclude that generalised exchange is characteristic of exchanges within direct family, whilst restricted exchange defines horizontal flows between peers, friends and neighbours (Degenne and Lebeaux, 1997: 124-125).

This article corroborates the perspectives of these authors. The research I carried out shows that different principles apply to different ties. Social networks are defined on the basis of the fundamental criterion that distinguishes family from others (Portugal, 2006), and the norms that apply to the flows between ties obey the same principle. The circulation of gifts has specific features depending on whether we look inside or outside the family.

As the authors of M.A.U.S.S. ${ }^{3}$ have emphasised, "giving, receiving and reciprocating" is not synonymous with reciprocity (Mermet, 1991; Caillé, 2000; Godbout, 2000). Giving in

\footnotetext{
${ }^{3}$ The M.A.U.S.S. Movement - Moviment Anti-Utilitariste en Sciences Sociales - founded in 1981, as Alain Caillé explains in his presentation to the Brazilian public, has "a negative side and a positive side." The negative side concerns the rejection of utilitarianism, the hegemonic ideology of modernity. The positive side seeks to develop the ideas of Marcel Mauss on the gift (Caillé, 2003: 16). The Movement, which emerged as a reaction
} 
order that another will give is not the same as giving in order to receive. An exchange under the aegis of a gift emerges as a sequence of actions that engender an imbalance in the positions of the actors involved. The sequence is based on a chain of donations and counterdonations and the reversibility of the positions of giver and receiver. This is an open-ended reality that is not constrictive, given that the chain can be broken or rejected at any time by any of the actors involved. The gift leads on to indeterminacy, to the possibility of constructing a shared meaning that is not restricted to repayment, but instead builds up a relationship in which those involved are never only givers or receivers. An analysis of concrete practices and behaviour shows that the freedom of giving, and the way in which it is linked with reciprocity, conforms to the complex interplay of different principles which act in diverse ways according to the network ties in question. If, up to a certain point, we can agree with Godbout when he affirms that kinship "keeps reciprocity at a distance" (Godbout, 2000: 34-36), it is impossible not to acknowledge a binary logic of reciprocity at work in relationships outside the family.

The concept of positive debt used by Godbout (2000) is more productive than reciprocity when analysing the circulation of gifts within the family. In a relationship, the condition of positive debt evades equivalence and makes each individual feel that $\mathrm{s} / \mathrm{he}$ is receiving more than $s /$ he is giving, although $s /$ he is always willing to reciprocate. Godbout's definition is particularly useful in terms of understanding family gifts, and, especially, intergenerational flows: "positive debt exists when the receiver perceives no intention on the part of the giver of making him/her indebted by his/her gesture - which is closely linked to the pleasure of being indebted, an essential element in the condition of positive debt" (Godbout, 2000: 47). This condition marks the discourse of most of the individuals whom I interviewed - debt was the expression used most frequently to refer to gifts from parents. On the one hand, parents

against the hegemony of the economicism of the social sciences that became established during the 1970s, now publishes the Revue du MAUSS and brings together a group of researchers from various areas. M.A.U.S.S. collaborators reject the dominant rationale, refusing to accept homo economicus as a concept of the individual, and the market as the main structuring element of society. Therefore, they seek out arguments that enable them to construct an alternative vision of the world. These arguments are supplied by the work of Marcel Mauss, in particular the ideas contained in his Essai sur le don. This work contains a "discovery" (Caillé's term) that is crucial to the movement: a certain universality, in ancient societies, of the triple obligation to give, receive and reciprocate. According to Mauss, the gift presents itself as a "total social phenomenon." Even if made by single individuals, the gift pervades all the dimensions of social action and has repercussions on the whole of society. In addition to its utilitarian aspect, it is essentially symbolic. Not only are gifts symbolic, but symbols must be understood as gifts. Thus, "the paradigm of the gift can equally be understood as a paradigm of symbolism" (Caillé, 2000: 125). 
had given them life itself, which is impossible to repay - although grandchildren are sometimes seen by children as a reward to their parents for their sacrifices. ${ }^{4}$ On the other hand, there is the notion that it is necessary to repay in some way, but that nothing "can ever repay" what has been given. Finally, as other studies have shown (Degenne and Lebeaux, 1997), there is almost a consensus on the lack of expectations on the part of parents who give in terms of repayment by their children - as one interviewee said, "they [the parents] enjoy helping us out much more than us helping them."

Being indebted to parents is both an economic debt and a debt of recognition. Material, affective and symbolic elements combine in a complex interplay which does not, however, totally disregard reciprocity. If kinship keeps reciprocity "at a distance," as Godbout says, it does not exclude it entirely, but rather allows it to take on different forms: it is "limited" (Godbout, 2000: 36), "deferred" (Bawin-Legros, 2003: 169), or "indirect" (Attias-Donfut et al., 2002: 263). In family reciprocity, giving and reciprocating, on the one hand, enable very different elements to circulate and be of equal value, whilst, on the other hand, time may elapse between the gift and counter-gift without breaking the cycle. It does not matter what is exchanged, or when. In this kind of giving, the more trust there is in the other, the less time matters. Mediated by affections and trust, reciprocity between family members often takes place on "a lifetime scale" and transforms help into a sort of "long-term credit" which does not need to be repaid immediately, nor to be symmetrical: the counter-gift can come much later or even be destined for another person (Bawin-Legros, 2003; Déchaux, 1990b; Finch, 1989). This concept also contains the clear idea of the evolution of the positions of the giver and the receiver over the lifetimes of parents and children. In childhood and youth, children only receive. In adulthood they both give and receive, although asymmetrically. When parents reach old age, they, in turn, become receivers and the implicit norm of reciprocity is finally put into practice (Bawin-Legros, 2003; Grundy, 2005; Schaber, 1995).

Care of the elderly is an example of how in family gifts the norm of reciprocity extends over the lifetime of a family and beyond restricted exchanges. Caring for parents in their old age is not just repayment for gifts received over the course of a lifetime, but also repayment for what they have given to their own parents. Thus, the same type of gift may involve

\footnotetext{
${ }^{4}$ In this way, generational continuity is part of the broader, long-term circuit of family giving, and undoubtedly represents one of the clearest expressions of the way in which kinship ties make the incommensurable equivalent.
} 
different actors at the time of giving and the time of repayment. As one interviewee says, "it's simple: they took care of me, and if some day I want someone to take care of me, then I have to take care of someone now." Children, parents and grandchildren are part of an intergenerational chain in which gifts circulate and reciprocity always comes around one day (Attias-Donfut et al., 2002).

Research shows, however, that the characteristics of reciprocity amongst relatives depend on the socio-economic characteristics of families. Although long-term reciprocity persists, amongst the parents and children of more disadvantaged families direct reciprocity increases (Jones, 1992; Martin, 1995). This type of reciprocity is particularly evident in material aid. Here, direct exchange is much clearer: children receive goods and services from parents, but are almost always bound by explicit repayment.

Outside family ties, everything takes place differently, since a binary logic of reciprocity prevails in gift giving. Non-family ties are the object of mistrust and great insecurity and exchanges must therefore be restricted. There are no guarantees beyond the pair involved, and expectations and demands are high and control is tight. If you give me something, I will repay you, and if I give you something I expect to be repaid: the balance has to be maintained, otherwise the bond is broken. It is not necessary to repay in kind, but the cycle should not be broken and should remain permanently active for the tie to remain intact.

In general, gift giving outside the family seems to be less rewarding and stimulating. On the one hand, debt is no longer seen as positive and takes on a negative meaning. Being indebted to someone makes individuals feel uneasy, and it is therefore necessary to rid oneself of this feeling. In some way, in the circulation of gifts outside the family, the principle of mercantile equivalence is installed in representations and practices. Freedom means not owing anything to anyone. Here, reciprocity is also a necessary condition in order to avoid domination of one partner by the another (Godbout, 2000: 59). On the other hand, when referring to ties outside the family, people tend above all to value their position as givers and often express feelings of injustice in relation the behaviour of others. ${ }^{5}$

\footnotetext{
${ }^{5}$ As one interviewee revealed in the following: "How can I put it ... when I'm a friend to someone... and I've always been like this ... I've never found anyone who's been the same to me, never... I mean, people outside the family ... I've never found anyone...".
} 


\section{Obligation, but ...}

To what extent does "giving, receiving and reciprocating" constitute an obligation? What do people understand by an obligation? Are family relationships more strongly marked by obligation and duty than other relationships? In their work Negotiating Family Responsibilities (1993), Janet Finch and Jennifer Mason respond negatively to the last of these questions, showing that the norms relating to family support are much less restrictive and generalised than may be thought. In a study carried out in England, the authors concluded that for most people responsibilities to relatives were not fixed and were much more fluid than the notions of "obligation" and "duty" imply. The authors argue that there is a "sense of responsibility" that is developed over time through the interactions of the individuals involved. A process of negotiation takes place in which people give and receive, offsetting one type of help with another, and maintaining a certain amount of independence as well as mutual interdependence. In this way, responsibilities are created and constructed rather than seen, from the outset, as inherent to a particular relationship.

My data does not allow me to subscribe to this perspective. The interviews I conducted revealed that obligations within a family are inscribed in relationships from the outset. Kinship is a given, rather than a construct: there is a notion of what is expected of a relative and of what $s /$ he can expect. The affective and instrumental importance of the family is based on the certainty that its members share the same idea of "how things should be." What the interviews showed was the prevalence, in individual representations, of the obligation of the family to "take care of its own."

Philippe Rospabé emphasises the ambiguity of the term "obligation," which can be applied to various institutions in which the constraint is of a different nature (Rospabé, 1996). The author distinguishes two meanings: in a technical and legal sense, an obligation defines a relationship recognised in law between two people, by virtue of which one individual may demand something of another. ${ }^{6}$ This legal bond establishes a debtor and a creditor, and the latter may demand "something" of the former on pain of legal sanctions. In addition to this restricted meaning, Rospabé also refers to obligation in a broader sense, i.e. a moral obligation resulting from a commitment that is not obligatory in the legal sense,

\footnotetext{
6 "An obligation is a legal bond by which one person is committed to providing something to another" (Article 397 of the Portuguese Civil Code).
} 
given that it is not subject to any sanctions of this kind, but which functions as an imperative (Rospabé, 1996: 142-143).

In Portugal, both meanings of the term contribute towards structuring the representations and practices of individuals. We can see both the importance of family values and the legal framework that reinforces these values. Family obligations are still enshrined in the fundamental laws which govern the lives of citizens ${ }^{7}$ and persist in the values which preside over family relationships, revealing "a cultural norm that acknowledges mutual aid between close relatives" (Wall, 1998: 329), as is evident in all surveys undertaken to date. ${ }^{8}$

Although family obligation is clearly internalised, there is some rejection of the term and a tendency to endow it with a negative meaning, namely as a form of constraint or coercion. ${ }^{9}$ The discourses reveal a tension between norm and duty, on the one hand, and freedom and affections on the other. It is as if the recognition of the existence of an a priori obligation cancelled out the effect of affections. In this way, obligation assumes various forms in an attempt to overcome the concept of imposed duty and to conceive of a route whereby "what should be done" is modulated by the relational domain and by individual choices and sentiments. Thus, the practices of caring, giving, receiving, and repaying within the family are no longer based on obligation and become defined as "demonstrations of affection," "giving back," "collaboration," "sharing" and "something you take pleasure in doing." ${ }^{10}$

This finding reveals the specific relationship between the gift system and norms. Not only are the real rules concealed, but others are expressed which tend to deny the prevailing

\footnotetext{
${ }^{7}$ In an analysis of the Portuguese laws on filial relations, João de Pina Cabral refers to the "radical familism" that inspired the Civil Code of 1966 (Pina Cabral, 1993: 988). The changes in 1977 did away with the figure of the head of household, established equality between men and women and recognised children born out of wedlock, but still enshrined the obligations of parents and children, and emphasised the idea that they should mutually assist each other.

${ }^{8}$ The fact that the overwhelming majority of Portuguese people agree with the assertion "we must love our father and mother, regardless of their qualities and faults" has led Ana Nunes de Almeida to state that "it is as if the biological bond, the blood tie, were an absolute natural fact that imposes incontestable duties on those who are offspring" (Almeida, 2003: 77).

${ }^{9}$ One interviewee stated: "Well, it's not an obligation... it's something ... it's something I enjoy, because my inlaws are fantastic and I think... I don't think anyone could have in-laws like mine. And that's the truth."

${ }^{10}$ Alcon et al. (1996), in a study on the discourse associated with family obligations, highlight the diverse meanings of the concept, ranging from absolute rejection of the idea and the defence of everything being voluntary, to the conviction of the need for the existence of a moral duty to ensure things are done.
} 
logic. ${ }^{11}$ This was one of the observations made by Mauss of ancient societies: where the researcher sees interest and obligation, the actors' discourse is one of free will and generosity. In reality, the elements of a gift system have a specific relationship to the rules. Firstly, "the rules of the gift must be implicit" (Godbout, 2000: 159). Secondly, actors tend generally to deny their obedience to a system of rules in an act of giving. The aim of a "true" gift is not to conform to a social convention or rule, but rather to express a tie with another person.

The discourses on this subject seem to reveal a trend that contradicts the one identified in other studies of family solidarity undertaken in the rest of Europe. Whilst in other countries, particularly in France, authors encountered an old discourse combined with new practices, and thus refer to a "new family spirit"12 (Attias-Donfut et al., 2002; Bawin-Legros, 2003), in Portugal I would point to the existence of old practices with a new discourse. ${ }^{13}$ There is an "old family spirit," based on clearly defined obligations which structure individual practices, that is linked to an innovative discourse in which autonomy, independence, democracy and affectivity are shown to be important factors in defining what "should be done" and what "is done."

The research shows, above all, how obligations are felt within the family, are essentially linked to blood ties and subject to a process of verticalisation within the network. However, it is possible to create obligations with non-relatives (Finch, 1989). This is not very common and is directed towards the few strong ties constructed through friendships. Given that these kinds of ties are marked by freedom, choice and risk, obligations outside the family are constructed entirely through the relationship with the other person and are based on reciprocity. The demands on relationships between friends are very strong, since nothing is taken for granted and everything is continually put to the test by the contributions made by each member of the pair. Obligations are based on the security of the continuing cycle of "giving, receiving and reciprocating" - I have an obligation to give and receive from a friend because $s /$ he does the same to me. Moreover, I only call her my friend when I am assured

\footnotetext{
${ }^{11}$ Bourdieu refers to the "taboo of explicitness" (1997: 124).

${ }^{12}$ The title of the latest book by Claudine Attias-Donfut, written in collaboration with Nicole Lapierre and Martine Segalen (Attias-Donfut et al., 2002).

${ }^{13}$ This is not limited to the questions discussed here. The coexistence, within the family, of traditional practices and progressive values and discourses has been underlined in various studies. One example is marriage: many people think that it is an "old-fashioned institution" but everyone gets married (Almeida, 2003: 54-55). Another
} 
that this will happen. If it does, then obligations can be as strong as those found inside the family.

\section{Equality, but ...}

The discourse of the interviewees on contributions, repayment and obligations within the network is very much marked by the principle of equality - "everyone should be given the same," "everyone has the same obligation." Equality seems to be a fundamental criterion in defining what is just. However, as already mentioned, this equality does not refer to reciprocity within the giver-receiver pair, but to the relationship between givers and receivers. It does not matter whether the child repays his/her parents; what matters is that the parents give the same to each of their children, and the children have an equal obligation to take care of their parents in their old age. The following statement from one of the interviewees illustrates this principle:

There was one thing my father always did very correctly ... if he gave fifty to one, he'd give fifty to the other. And I never ask if he's given my sister anything. He's always the first to say ... I gave such-and such to your sister, so I'm giving this to you.

Failure to apply the principle of equality to one's children is one of the main reasons for tensions and conflicts between parents and children, as well as between siblings, and one of the fundamental reasons for family splits. Given that the principle of equality applies to the relationship between givers and receivers, the problems go beyond the giver-receiver pair and apply generally to the group involved. If they feel they have been treated unfairly, children get involved in conflicts with their elders and also with members of their own generation for "siding" with these inequalities. Conflicts within close family relationships almost always involve disputes about the unequal contributions and repayments of parents, children and siblings.

The norm of equality is above all fundamental in defining the circulation of gifts from the top downwards. Treating one's children equally is an inalienable principle of family relationships, and becomes particularly significant when it is a question of material donations from parents to children. Symbolic, affective and legal issues help to make this the case. The legal rights of each individual are added to the moral obligation of parents and, for 
this reason, inheritance emerges as the final regulator of gifts. The principle of equality may sometimes be broken, with or without a consensus, but the discourses convey the certainty that "in the end" everything will be settled properly.

The definition and application of the principle of equality to the circulation of family gifts are somewhat complex. Coenen-Hunter et al. (1994), in a study on family solidarity, discuss the application of the principles of distributive justice to the processes of negotiating mutual support, reaching the conclusion that the definition of the roles of the different members of the family network in providing support is essentially made on the basis of two principles: equality and equity. The equality principle requires that everyone should contribute equally, given that they have similar status. The equity principle, on the contrary, presupposes that the contribution of each person should conform to certain criteria: socio-economic resources and/or concrete availability (time, geographical proximity, etc.); gender and order of birth (daughters, oldest children, etc.); skills (technical and/or relational). In the case of the equity principle, the criteria for dividing up obligations vary according to the type of help required (money, household services, moral support, etc.) (Coenen-Hunter et al., 1994: 152).

My research findings are very close to these. Firstly, the study by Coenen-Hunter et al. shows that the equity norm prevails to a great extent over the equality norm (CoenenHunter et al., 1994: 153). Secondly, the authors' work on distributive justice reveals that very diverse criteria intervene in the inventory of resources, in most cases creating conflict between the actors involved. Finally, the study on family solidarity reveals that very often difficulties are resolved in terms of the most simple criteria (geographical proximity, work timetables, etc.) without the individuals involved necessarily being satisfied.

The interviews I conducted show clearly that, depending on the resource in question, the dominant discourse reflecting the equality principle is, in practice, replaced by the equity principle. Equality prevails in few areas: primarily in financial help and material goods. Here, the same is given to all children: the same money, the same land, the same present, a financial amount equivalent to the price of the land or present, etc. However, when it is a matter of help with services or care, everything changes: help is given to the person who is nearest, who needs it most or who asks for it. The equity principle then prevails and the flows are no longer governed by equality: they are unequal between parents and children, children and parents, grandparents and grandchildren, grandchildren and grandparents and between siblings. Contributions differ according to whether a man or a woman is involved, 
whether they live near or farther away, and whether they are able to contribute or not. It should be emphasised that these ambiguities are actually acknowledged in the discourse of interviewees. People proclaim the principle of equality but admit that it is difficult to apply "everyone has the same obligation, but..." Certain attributes prevail without causing any greater problems: being a woman and living nearest, for example, are variables that "naturally" lead people to assume a greater burden without creating conflict.

As Coenen-Hunter et al. emphasise, the equity principle also conveys an expression of individualism and potential conflict between members of the family network: it is necessary to reckon things up, but the criteria used in the calculations are not always compatible and cannot always be properly ranked. As different types of help flow (money, goods, services) according to variable criteria, the authors question whether the difficulty of determining the cost of each one may not represent a factor that is liable to limit solidarity. In effect, whilst a feeling of injustice, linked to poor reckoning of the legitimate criteria, may be tolerated when the costs are low, the same cannot automatically be said to happen once they increase (Coenen-Hunter et al., 1994: 155).

\section{Autonomy, but ...}

If the equality principle pervades discourse on the circulation of family gifts, the autonomy principle characterises the way in which people define their relationships with others, particularly the older generations. The expression of autonomy ranges from the norm of "casamento-apartamento" ("marriage and own home"), which presides over the setting up of a family and defines residential strategies, ${ }^{14}$ to the motto "everyone has to lead their own life," which is used repeatedly to describe the relationship with parents and in-laws as well as other close relationships. The primacy of the nuclear family involves the affirmation of autonomy and the principle of not interfering with what happens within it. "Only those who live in the convent know what goes on inside" - the husband, wife and children are the only ones who have the right to talk about how family life is organised and the decisions that are made. All choices concerning the details of daily life and professional and educational

\footnotetext{
${ }^{14}$ An interesting discussion of the relationship between autonomy and housing can be found in Sennett (2004). The author states that ownership of a house is a "compelling desire in American society" and sees this as one manifestation of its individualism (Sennett, 2004: 112).
} 
options centre on this triad, and any interference is considered abusive, particularly if unsolicited.

As the processes involved in the transition to adult life are becoming increasingly complex, diverse and spread out over time (Cicchelli and Martin, 2004; Guerreiro and Abrantes, 2004), the "set-up time" for most of the families interviewed is based, to a large extent, on intergenerational support strategies. The interviews show how, in a social context in which the market is making it increasingly difficult to access employment and housing and economic instability is also increasing, it is becoming harder for individuals and their families to establish their autonomy in relation to the previous generation. However, both generations continue to favour autonomy for young families, with parents being the first to provide the support to enable this to be constructed gradually. ${ }^{15}$

Given the intense material and affective flows that circulate from parents to children, the balance between giving, reciprocity and autonomy is difficult to achieve and represents a complex element in the management of families. As Claude Martin (1996) states, family giving is accompanied by the "right of intromission," which contrasts with the principles of autonomy. The research shows that this is an area of tension within networks, given that conflicting norms are at stake. The challenge facing new families is to reach a compromise between individuality and freedom and between obligation and autonomy, which is not always easy to achieve.

As the reflections of the French sociologist François de Singly on family and individualisation have shown (Singly, 2001a, 2001b, 2001c, 2001d, 2003 and 2004), nowadays a significant part of the personal identity of individuals is constructed within the domain of family relationships, where love circulates. In individualistic societies, "the family" (whatever its form or structure) assumes the role of consolidating the "self" of adults and children. Contrary to what the term individualism may lead us to believe, in order to construct their identity, individuals need relationships with others whom they regard as important. These significant others are generally their spouses and children or, from the children's point of view, their parents.

\footnotetext{
${ }^{15}$ On this subject, see the collection compiled by Singly (2001c) on the process of individualization of children and young people.
} 
Singly's work shows how the changes that took place in families correspond to a compromise between the individuals' claims for autonomy and their desire to continue to share their private life with those close to them from an affective point of view. The "individualistic and relational family" which the author talks about (Singly, 2004) offers the possibility of happiness for all of its members. The affective relationship provides a favourable framework in which personal identity is not diminished but, on the contrary, gradually revealed. It is not merely a matter of being together with someone, but of being freely together (Singly, 2001a). ${ }^{16}$

The family is constructed on the basis of love, but the most fundamental thing about it is not the institution itself but its members - "the family becomes a private space at the service of individuals" (Singly, 2001b: 8), ${ }^{17}$ enabling its members to become individualised. For this reason it is both attractive (given that the majority of individuals prefer it as a way of life) and unstable (the marital tie is becoming increasingly fragile and the duration of relationships increasingly unpredictable). As Singly affirms, it is "in the tension between relations and autonomy that contemporary families are constructed, deconstructed and reconstructed" (ibid.).

I intend to avoid falling into the trap of confusing autonomy with independence. As Karine Chaland (2001) clearly explains, the two notions have different philosophical roots and correspond to very separate theoretical and empirical realities. Briefly, we may say that the concept of autonomy refers to the construction of one's own rules, whilst the idea of independence refers to the individual's self-sufficiency and possession of resources (specifically, economic resources), which enable her/him to be free to establish the ties s/he wants. According to the individualistic ideas of contemporary societies, individuals should be autonomous and independent (Singly, 2001a). However, as Chaland stresses, it may not be possible for the two dimensions to coexist. Analysing the case of young unemployed adults, the author shows that it is possible to be autonomous without being independent (Chaland, 2001: 36-39). The "most radical" combination of the two dimensions is to be found amongst

\footnotetext{
${ }^{16}$ The title of a work by Singly: Libres ensembles. L'individualisme dans la vie commune (2001a). The closeness of some of the author's positions on the link between individualisation and married life to the arguments put forward by Anthony Giddens and to his concept of the "pure relationship" (Giddens, 1994 and 1995) should be stressed.

${ }^{17}$ This trend is evident in various indicators: divorce by mutual consent, the increased number of working women, the preference for negotiation in bringing up children, etc. (Singly, 2001b and 2001c).
} 
employed single people (idem: 40): individuals who work, live alone and are not involved in any intimate relationship. Thus, Karine Chaland's analysis clearly shows that autonomy and independence may exist in association or dissociation. My interviews confirmed this idea.

If autonomy prevails, independence is not always a constant. Research shows that there are families who are totally independent of their original families in both material and affective terms; families who have close affective relationships with the older generations and are intensely sociable but enjoy total material independence; families who are financially independent but still need material support and/or services provided by the previous generation; families who depend on their original families in order to maintain a lifestyle beyond their financial means; and families who depend on various forms of support from their original families on an everyday basis in order to survive.

As Hockey and James show (1993), "dependence" is a possibility for each individual during his life cycle. This is a concept that has more than one meaning and includes a wide range of contexts and social experiences. However, in western societies nowadays, the expression tends to refer to an increasingly restricted set of experiences and specific categories of individuals, whilst also assuming increasingly negative connotations. ${ }^{18}$

These concepts lose their meaning when a micro-sociological perspective on the family is constructed in the light of the gift paradigm. Even when considered from a macro-social point of view, it is possible to observe that the period of dependence on the family is becoming extended - youth is lasting longer and the processes of transition to adult life, as previously mentioned, are becoming increasingly complex. ${ }^{19}$ Within the family, dependence is part of the web of ties that are established between its members and of the constellation of greater or lesser conflicting principles that govern relationships within the network.

It is the ambiguity that exists between the need for autonomy and the complex web of dependencies established through the help provided by relatives that partly explains the logic of dissimulation discussed above. Givers must take care not to threaten the autonomy of recipients and not to transform them into dependents. For those who receive, it is

\footnotetext{
18 Sennett refers to the "shame of dependence" (2001: 214-217) and in his latest work discusses the "infantilization thesis" which liberal thought has constructed around dependence (2004: 102-107).

${ }^{19}$ In analysing data from a survey of young Portuguese people (aged 15 to 29), Luísa Schmidt concludes that "marriage, which was one of the most reliable criteria or indicators of social autonomisation and of change in status from young person to 'adult', in the end is shown to represent the prolongation of a characteristically juvenile situation for many young couples," or, according to the author, "a situation of semi-dependence on
} 
necessary to ensure independence without jeopardising the support provided by relatives. For this reason, asking is forbidden, although the generosity of the family is always welcome. Those who know how to generate help without asking and those who give disinterestedly and discreetly are at an advantage.

Dependence is a relational term that raises questions about the nature and quality of the relationships that are established. Although individualist theses emphasise the negative aspects, my empirical analysis does not provide enough elements to confirm this. The interviews show that countless families depend on their original families in different ways and to different extents. Although this fact gives rise to some tension at certain moments, dependency is inscribed in the long cycle of family gifts and counter-gifts, enabling obligation and liberty to be reconciled. Research shows that individuals and their families seek out a balance that does not threaten their identity and individuality, constructing models that reconcile autonomy, independence and relationships with others.

\section{Final considerations}

From what has been discussed in this article, it emerges that the definition and application of norms within social networks conform to a complex model. Interactions and exchanges are based on principles that very often contradict each other and generate tensions and conflicts. Dependence on the support which flows within networks collides with the basic principle of autonomy, the senses of duty and obligation are at odds with freedom and affection, the norm of reciprocity evades the asymmetry of exchanges, giving coexists with utilitarian interests, the principle of equality is obscured by the social and gender inequalities that define the kind of help that is given. This series of paradoxes is primarily founded on the difference between kinship and other types of ties.

The research presented here shows that norms are applied differently within and outside family ties. Kinship represents a subsystem within networks, given that the relationships that it establishes are defined by a priori constitutive, regulatory and distributive norms. Networks define forms of exclusion and inclusion and offer protection or indifference on the basis of the criteria of trust or lack of trust. The interviews show that biological relationships 
offer individuals the security that other ties do not contain, whilst also imposing clear obligations and duties.

In his work The Corrosion of Character, Richard Sennett (1998) analyses the new organisation of work and discusses the way in which modern institutions are supported by schemes which favour the short term, thus limiting the strengthening of informal trust. The slogan is "No long term" - "a principle which corrodes trust, loyalty, and mutual commitment" (Sennett, 1998: 23). The author stresses the devaluing of strong ties and the importance of weak ties in a context of permanent change, in which distance and superficial cooperation are more beneficial than loyalty and commitment. Sennett identifies a conflict between work and family, a sphere in which the long term and mutual commitment are fundamental. From this conflict the author extracts certain questions on the "adult experience": "How can long-term purposes be pursued in a short-term society? How can durable social relationships be sustained? How can a human being develop a narrative of identity and life history in a society that is composed of episodes and fragments?" (Sennett, 1998: 26-27).

In the light of what has been discussed here, the answer to these questions seems to lie in family ties. One of the aspects that upholds the strength of family ties is the enduring nature of relationships. Family ties offer a long-term perspective missing from other relationships that are more susceptible to changes of various kinds and to erosion by time. It is the permanence of family relationships, guaranteed by the biological bond, that to a large extent enables trust and mutual commitment to be built up, representing instrumental and affective anchors for individuals and their families. In this way, family ties constitute structuring elements in the design of social networks.

Therefore, in the contemporary process of individualisation, the fragility of the conjugal tie (Singly, 2001b) and the labour tie (Sennett, 1998) are not, in this case, paralleled by any weakening of kinship ties. The role and normativity of family relationships are revealed in multiple forms, enabling their vitality and their importance to the configuration of social networks to be affirmed. If, as Martuccelli affirms, "the individual only exists to the extent that that he is sustained by a series of supports" (2002: 63), research shows that family ties are an essential form of support.

Analysis of the norms within networks shows that kinship has alchemical properties: it turns difference into equivalence, provides for dependence without loss of autonomy, 
reconciles freedom with obligation, and transforms debt into a positive element. This alchemy is possible due to the predominance of the gift system and the primacy of social ties over things in defining relationships between individuals.

Translated by Sheena Caldwell

Revised by Teresa Tavares

\section{References}

Alcon, Carmen Dominguez; Bertaut, Mónica Becue; Reinert, Max (1996), "Obligations familiales et solidarité. Analyse statistique du texte des entretiens," in AIDELF, Ménages, familles, parentèles et solidarités dans les populations méditerranéennes. Paris: PUF.

Almeida, Ana Nunes de (2003), "Família, conjugalidade e procriação: valores e papéis," in Jorge Vala et al. (eds.), Valores sociais: mudanças e contrastes em Portugal e na Europa. Lisbon: Imprensa de Ciências Sociais, 47-93.

Attias-Donfut, Claudine; Lapierre, Nicole; Segalen, Martine (2002), Le nouvel esprit de famille. Paris: Éditions Odile Jacob.

Bawin-Legros, Bernadette (2003), Le nouvel ordre sentimental. À quoi sert la famille aujourd'hui? Paris: Payot.

Boissevain, Jeremy (1974), Friends of Friends. Networks, Manipulators and Coalitions. Oxford: Basil Blackwell.

Bourdieu, Pierre (1997), Razões práticas. Sobre a teoria da acção. Oeiras: Celta [English translation: Practical Reason: On the Theory of Action. Stanford: Stanford University Press, 1998].

Cabral, João de Pina (1993), "A lei e a paternidade: as leis de filiação portuguesas vistas à luz da antropologia social," Análise Social, 123-124, 975-997.

Caillé, Alain (2000), Anthropologie du don. Le tiers paradigme. Paris: Desclée de Brouwer.

Caillé, Alain (2003), "Dádiva, cidadania e democracia," in Alzira Medeiros; Paulo Henrique Martins (eds.), Economia popular e solidária. Desafios teóricos e práticos. Recife: Edições Bagaço,16-25.

Chaland, Karine (2001), "Pour une usage sociologique de la double généalogie philosophique de l'individualisme," in François de Singly (ed.), Être soi d'un âge à l'autre. Paris: L'Harmattan, 31-43.

Cicchelli, Vincenzo; Martin, Claude (2004), "Young Adults in France: Becoming Adult in the Context of Increased Autonomy and Dependency," Journal of Comparative Family Studies, 35(4), 615-626.

Coenen-Hunter, Josette; Kellerhals, Jean; von Allmen, Malik (1994), Les réseaux de solidarité dans la famille. Lausanne: Éditions Réalités Sociales.

Déchaux, Jean-Hugues (1990a), "Les échanges économiques au sein de la parentèle," Sociologie du Travail, 1, 73-94.

Déchaux, Jean-Hugues (1990b), “Des relations de parenté inédites?” Esprit, 91-101. 
Degenne, Alain; Forsé, Michel (1994), Les réseaux sociaux. Paris: Armand Colin.

Degenne, Alain; Lebeaux, Marie-Odile (1997), “Qui aide qui, pour quoi?” L'Année Sociologique, 47(1), 117-141.

Ferrand, Alexis (1992), "Les réseaux de relations personnelles," Actes du Séminaire "Du politique et du social dans l'avenir de la famille." Paris: La Documentation Française, 79-90.

Finch, Janet (1989), Family Obligations and Social Change. Cambridge: Polity Press.

Finch, Janet; Mason, Jennifer (1993), Negotiating Family Responsibilities. London: Routledge.

Giddens, Anthony (1994), Modernidade e identidade pessoal. Oeiras: Celta [Portuguese translation of Modernity and Self-Identity. Stanford: University Press, 1991].

Giddens, Anthony (1995), Transformações da intimidade. Sexualidade, amor e erotismo nas sociedades modernas. Oeiras: Celta [Portuguese translation of The Transformation of Intimacy: Sexulaity, Love, and Eroticism in Modern Societies. Stanford: University Press, 1993].

Godbout, Jacques T. (1995), "La norme de justice dans les relations de parenté," L'Année Sociologique, 45(2), 351-370.

Godbout, Jacques T. (2000), Le don, la dette et l'identité. Paris: La Découverte.

Granovetter, Mark S. (1973), "The Strength of Weak Ties," American Journal of Sociology, 78, 1360-1380.

Granovetter, Mark S. (1982), "The Strength of Weak Ties: A Network Theory Revisited," in Peter V. Marsden; Nan Lin (eds.), Social Structure and Network Analysis. Beverly Hills: Sage, 105-130.

Grundy, Emily (2005), "Reciprocity in Relationships: Socio-economic and Health Influences on Intergenerational Exchanges Between Third Age Parents and their Adult Children in Great Britain," British Journal of Sociology, 56(2), 233-255.

Guerreiro, Maria das Dores; Abrantes, Pedro (2004), Transições incertas: os jovens perante o trabalho e a familia. Lisbon: DGEEP/ CITE.

Hockey, Jenny; James, Allison (1993), Growing Up and Growing Old. Ageing and Dependency in the Life Course. London: Sage.

Jones, Gill (1992), "Short-term Reciprocity in Parent-Child Economic Exchanges," in Catherine Marsh; Sara Arber (eds.), Families and Households. Divisions and Change. London: Macmillan Press, 26-44.

Kellerhals, Jean; Coenen-Huther, Josette; Modak, Marianne (1987), "Stratification sociale, types d'interaction dans la famille et justice distributive," Revue Française de Sociologie, XXVIII, 217-240.

Kellerhals, Jean; Coenen-Huther, Josette; Modak, Marianne (1988), Figures de l'équité. La construction des normes de justice dans les groupes. Paris: PUF.

Kellerhals, Jean; Modak, Marianne; Sardi, Massimo (1995), "Justice, sens de la responsabilité et relations sociales," L'Année Sociologique, 45(2), 317-349.

Lemieux, Vincent (1999), Les réseaux d'acteurs sociaux. Paris: PUF. 
Martin, Claude (1995), “Os limites da protecção da família. Introdução a uma discussão sobre as novas solidariedades na relação família-Estado," Revista Crítica de Ciências Sociais, 42, 53-76.

Martin, Claude (1996), "Solidarités familiales: débat scientifique, enjeu politique," in JeanClaude Kaufmann, Faire ou faire-faire? Familles et services. Rennes: Presses Universitaires de Rennes, 55-73.

Martins, Paulo Henrique (2005), "A sociologia de Marcel Mauss: Dádiva, simbolismo e associação," Revista Crítica de Ciências Sociais, 73, 45-66.

Martuccelli, Danilo (2002), Grammaires de l'individu. Paris: Gallimard.

Mauss, Marcel (1988), Ensaio sobre a dádiva. Lisboa: Edições 70 [Portuguese translation of Essai sur le don, 1924]

Mermet, Jean-Claude (1991), "Le Lien de famille: la reciprocité en défaut," Revue du MAUSS, $12,137-146$.

Portugal, Sílvia (2006), Novas famílias, modos antigos. As redes sociais na produção de bemestar. Coimbra: FEUC (PhD dissertation).

Rospabé, Philippe (1996), "L’ obligation de rendre," Revue du MAUSS, 8, 142-152.

Schaber, Gaston (1995), "Don de temps, don d'argent, don d'espace," in Claudine AttiasDonfut (ed.) Solidarités entre générations. Vieillesse, familles, État. Paris, Nathan, 97115.

Schmidt, Luísa (1990), "Jovens: família, dinheiro, autonomia," Análise Social, 108-109, 645673.

Sennett, Richard (1998) The Corrosion of Character. The Personal Consequences of Work in the New Capitalism. New York: W.W. Norton.

Sennett, Richard (2004), Respect in a World of Inequality. New York: W. W. Norton.

Singly, François de (ed.) (2001c), Être soi parmi les autres. Paris: L'Harmattan.

Singly, François de (ed.) (2001d), Être soi d'un âge à l'autre. Paris: L'Harmattan.

Singly, François de (2001a), Libres ensembles. L'individualisme dans la vie commune. Paris: Nathan.

Singly, François de (2001b), "La naissance de l'individu individualisé et ses effets sur la vie conjugale et familiale," in François de Singly (ed.), Être soi parmi les autres. Paris: L'Harmattan, 5-14.

Singly, François de (2003), Les uns avec les autres. Quand l'individualisme crée du lien. Paris: Armand Colin.

Singly, François de (2004), Sociologie de la famille contemporaine. Paris: Armand Colin.

Therborn, Göran (2002), "Back to Norms! On the Scope and Dynamics of Norms and Normative Action," Current Sociology, 50(6), 863-880.

Torres, Anália et al. (2004), Homens e mulheres entre trabalho e família. Lisbon: DEEP/CID.

Wall, Karin (1998), Famílias no campo. Passado e presente em duas freguesias do Baixo Minho. Lisbon: D. Quixote. 